\title{
Alternatives to Bankruptcy in South Africa \\ That Provides for a Discharge of Debts: \\ Lessons from Kenya
}

Z Mabe*

\section{P.E.R}

Pioneer in peer-reviewed, open access online law publications

Author

Zingapi Mabe

Affiliation

University of South Africa

Email

mabez@unisa.ac.za

Date Submission

23 July 2018

Date Revised

4 February 2018

Date Accepted

16 February 2018

Date published

12 March 2019

Editor Prof H Chitimira

How to cite this article

Mabe Z " Alternatives to Bankruptcy in South Africa That Provides for a Discharge of Debts: Lessons from Kenya" PER / PELJ 2019(22) - DOI

http://dx.doi.org/10.17159/17273781/2019/v22i0a5364

Copyright

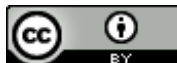

DOI

http://dx.doi.org/10.17159/17273781/2019/v22i0a5364

\begin{abstract}
The problems faced by debtors in South Africa is not that there are no alternatives to insolvency proceedings, but that the available alternatives do not provide for a discharge of debt as with a sequestration order, which is ultimately what the debtor seeks to achieve. Debtors in South Africa can make use of debt review in terms of the National Credit Act 34 of 2005 or administration orders in terms of the Magistrates' Court Act 32 of 1944 to circumvent the sequestration process. However, both debt review and administration orders do not provide for a discharge of debt and provide for debt-restructuring only, in order to eventually satisfy the creditor's claims. Attention is given to the sequestration process and the alternatives to sequestration as they relate specifically to the discharge or lack of a discharge of a debtor's debts. The South African law is compared to Kenyan Law. This article seeks to analyse the alternatives to the bankruptcy provisions of the newly enacted Kenyan Insolvency Act 18 of 2015 in order to influence the possible reform of insolvency law in South Africa. Like the South African Insolvency Act, the old Kenyan Bankruptcy Act (Cap 53 of the Laws of Kenya) also did not have alternatives to bankruptcy. The old Kenyan Bankruptcy Act, however, contained a provision on schemes of arrangement and compositions. The Kenyan Insolvency Act now caters for alternatives to bankruptcy and provides a wide range of alternatives to bankruptcy, some of which allow debtors in different financial positions to obtain a discharge.
\end{abstract}

\section{Keywords}

Kenya; bankruptcy; insolvency law; alternatives to bankruptcy; alternatives to sequestration, debt review, administration orders, debt intervention. 


\section{Introduction}

A problem faced by over-indebted individual debtors in South Africa is not that there are no alternatives to the sequestration proceedings, but rather that the available alternatives do not provide for a discharge of debt, which is one of the objectives the debtor seeks to achieve. The World Bank Report mentions that one of the principal purposes of an insolvency system for natural persons is to re-establish the debtor's economic capability through a discharge of debts. ${ }^{1}$ In South Africa, an insolvent is automatically rehabilitated and discharged from debts after the expiry of a period of 10 years from the date of sequestration. ${ }^{2}$ As the discharge of debts in South Africa occurs only after a fairly long period of time, there is a dire need for alternative legislative interventions that would also allow debtors in different financial positions to obtain a discharge of debts. To achieve this goal many countries have developed alternatives to bankruptcy, ${ }^{3}$ which either reduce the period of bankruptcy ${ }^{4}$ or provide a discharge of debt without experiencing all the limiting consequences of bankruptcy. ${ }^{5}$ In Kenya the

* Zingapi Mabe. LLB LLM (University of Pretoria). Senior Lecturer, University of South Africa. E-mail: mabez@unisa.ac.za. The author would like to acknowledge the financial assistance provided by Unisa's College of Law Research and Innovation Committee (CRIC) during the research for and writing of this article, including a grant to attend and deliver a paper (on which this article is based) at the Insol International Academics Colloquium held in London, United Kingdom on 11-13 July 2018. However, the views and conclusions contained in this article are the author's and the author absolves Unisa's College of Law from any responsibility that may arise therefrom. The author further wishes to express her thanks to Professor Michel KellyLouw for her valuable insights and comments, which improved the article.

World Bank Report paras 359-360.

An insolvent may also apply to court for his rehabilitation after the expiry of certain periods after sequestration. See ss 124(1)-124(5), 127A of the Insolvency Act 24 of 1936 (hereafter the Insolvency Act); Meskin et al Insolvency Law para 14.2; Bertelsmann et al Mars para 25.1.

3 The United Kingdom is pro-debtor and this can be seen in the one year automatic discharge period and the provision of individual voluntary agreements (IVA) and debt relief order (DRO), both of which provide for earlier discharge periods. See Part VIII and Part 7A of the United Kingdom's Insolvency Act, 1986 (hereafter the UK's Insolvency Act); Walters 2009 IIR 5; Fletcher Law of Insolvency. Australia has personal insolvency agreements (PIA) under Part $X$ of the Australian Bankruptcy Act, 1966 (hereafter the Australian Bankruptcy Act) and debt agreements (DA) under Part IX of the same Act. The Australian Bankruptcy Act was recently amended by the Insolvency Law Report Act, 2016 (hereafter the ILRA). The ILRA came into force on 29 February 2016 and commenced on 1 March 2017. The aim of the ILRA is to amend the law relating to personal and corporate insolvency and for related purposes, more especially to amend the Bankruptcy Act, 1966, the Bankruptcy (Estate Charges) Act, 1997 and the Corporations Act, 2001.

$4 \quad$ In this article the terms bankruptcy, bankruptcy procedure and sequestration process are considered as synonyms and are used interchangeably.

5 A sequestration order diminishes an insolvent's legal capacity, his capacity to contract, his capacity to litigate and his capacity to earn a living and to hold certain 
alternatives to the bankruptcy provisions are contained in section 14 of the Kenyan Insolvency Act. ${ }^{6}$ The new Act came into force in 2015 and it repealed the old Bankruptcy Act $^{7}$ and the old Companies Act. ${ }^{8}$

The legislative mechanisms available to over-indebted debtors in South Africa are: ${ }^{9}$ sequestration in terms of the Insolvency Act; administration orders provided for in section 74 of the Magistrates' Courts Act; ${ }^{10}$ and the debt review process provided for in terms of the National Credit Act. ${ }^{11}$ Administration orders and debt review have been classified as true debtrelief mechanisms, while sequestration, accurately speaking, is not intended to be a debt-relief mechanism available to over-indebted individual debtors, although it has the same end result and serves the same purpose. ${ }^{12}$ The Insolvency Act provides for a legislative process by which the assets of the debtor are distributed amongst his creditors. One of the consequences of a debtor's estate's being sequestrated is that it provides for a discharge of the debtor's debts. In contrast, debt review and administration orders are more focussed on bringing relief to the debtor regarding his debts than on providing him with a discharge of his debts.

Although the Draft National Credit Amendment Bill will not be discussed in detail in this article, it is important to mention that it introduces debt intervention in clause 14. ${ }^{13}$ The debt intervention in clause 14 extinguishes part or all of the obligations for a certain class of debtors. ${ }^{14}$ Certain debtors may also apply for rehabilitation. ${ }^{15}$ However the debt intervention will be applicable only to debts of not more than R50 000 and which arose as a result of credit agreements.

This article investigates whether the current alternatives to the sequestration process allow debtors in different financial positions to obtain

offices. See Ex parte Taljaard 19753 SA 106 (O) 108; Standard Bank of SA Ltd v Essop 19974 SA 569 (D) 575; Boezaart Law of Persons 144ff; Sharrock, Van der Linde and Smith Hockly's Insolvency Law 57; Smith Law of Insolvency 100.

Insolvency Act 18 of 2015 (hereafter the Kenyan Insolvency Act or new Act).

Bankruptcy Act (Cap 53 of the Laws of Kenya) (hereafter the old Bankruptcy Act).

Companies Act (Cap 486 of the Laws of Kenya) (hereafter the old Companies Act).

For a detailed discussion of the workings, benefits and disadvantages of the different mechanisms, see Nel Analysis of the Legislative Mechanisms; Coetzee 2017

THRHR 20; Coetzee 2016 IIR 36-39.

10 Magistrates' Courts Act 32 of 1944 (hereafter the MCA).

$11 \quad$ National Credit Act 34 of 2005 (hereafter the NCA).

12 Nel Analysis of the Legislative Mechanisms 3.

13 See clause 14 of the Draft National Credit Amendment Bill, 2018 (hereafter the Draft Bill) which is added to Chapter 4 after Part D of the NCA.

14 See the added s $88 \mathrm{C}$ (4) under clause 14 of the Draft Bill.

15 See the added s $88 \mathrm{E}$ under clause 14 of the Draft Bill. 
a formal discharge of their debts. In order to achieve this, I will consider the current alternatives to the sequestration process available for natural person debtors in South Africa, namely administration orders and debt review. There is no intention to discuss these alternative debt relief mechanisms in any specific detail. A legal comparative investigation is done with Kenyan law, with the aim of making recommendations for law reform in South Africa regarding alternatives to sequestration that will allow debtors in different financial positions to obtain a discharge of debts in South Africa.

The inclusion of Kenyan law was based on my desire to choose a country with a mixed legal system similar to that of South Africa and a country that shares similar legal origins to South Africa, which has already reformed its insolvency legislation. Kenya has a common law background with an English influence, its insolvency legislation borrowed extensively from the UK's Insolvency Act, and its insolvency law was consolidated into a single Act in 2015. Kenya' newly enacted Insolvency Act contains a wide range of alternatives to bankruptcy, which at face value appear to achieve the purpose of legislative interventions that allow debtors in different financial positions to obtain a discharge.

\section{South African sequestration process}

It is important to mention that sequestration may not be the inevitable result for every over-indebted debtor who becomes insolvent. A sequestration order in South Africa in terms of the Insolvency Act may either be obtained by the debtor's voluntarily surrendering his insolvent estate or a creditor of the debtor's applying for the sequestration of the debtor's insolvent estate. In either case, a sequestration order in South Africa will not be granted unless it is shown that the sequestration will be to the advantage of the creditors of the debtor. ${ }^{16}$ This requirement has shown to be the most difficult to prove, more so in voluntary surrender applications. ${ }^{17}$ When applying for a voluntary surrender of his estate, a debtor has to show that he has enough assets that can be realised to pay for the costs of sequestration and, most importantly, that the sequestration will be to the benefit of creditors (eg, all the creditors will receive a dividend). ${ }^{18}$ In contrast, for the compulsory sequestration of a debtor's estate brought by a creditor of a debtor, the

16 Bertelsmann et al Mars paras 3.30, 5.35.

17 Nel Analysis of the Legislative Mechanisms 3, 11; Coetzee 2016 IIR 36-39.

18 Section 6(1) of the Insolvency Act; Ex parte Arntzen (Nedbank Ltd as Intervening Creditor) 20131 SA 49 (KZP) 50 (hereafter Ex parte Arntzen); Roestoff Kritiese Evaluasie van Skuldverligtingsmaatreels 343. See Bertelsmann et al Mars para 3.30 for a discussion of the concept "advantage of creditors" in relation to voluntary surrenders. 
creditor needs to prove only that there is reason to believe that it will be to the advantage of the debtor's creditors if the debtor's estate is sequestrated. ${ }^{19}$

As indicated, one of the consequences of a debtor's estate's being sequestrated is that it provides for a discharge of the debts upon rehabilitation. ${ }^{20}$ The discharge can happen automatically after 10 years or earlier on application by the insolvent debtor. ${ }^{21}$ As a result, over-indebted and desperate debtors have in the past used somewhat fraudulent means to access the sequestration process ${ }^{22}$ and to eventually obtain a discharge of their debts upon rehabilitation. ${ }^{23}$

The advantage requirement of the sequestration process prevents those debtors who want to access the sequestration process only to obtain a discharge from their debts. ${ }^{24}$ However, because the discharge of debts in South Africa occurs only after a fairly long period of time, there is a dire need for alternative legislative interventions that would also allow debtors in different financial positions to obtain a discharge of their debts.

\section{South African debt-relief measures outside of the sequestration process}

Outside the sequestration process, if creditors have not commenced the individual debt collection process to recover their debts, ${ }^{25}$ over-indebted debtors may make an application to a debt counsellor to be declared over-

19 Mabe and Evans 2014 SA Merc LJ 656; Sharrock, Van der Linde and Smith Hockly's Insolvency Law 33.

$20 \quad$ Bertelsmann et al Mars 555; Nel Analysis of the Legislative Mechanisms para 5.6.

21 See S 127A of the Insolvency Act; Meskin et al Insolvency Law para 14.2; Bertelsmann et al Mars para 25.1.

See Mabe 2017 THRHR 695, where Mabe explains how a debtor in Nedbank Limited $\checkmark$ Malan; In re: Ex parte Application of Malan $2015 \mathrm{JOL} 33458$ (GP) used the process of voluntary surrender in $s$ 4(1) of the Insolvency Act to activate the suspension of sales in execution in s 5(1) of the Insolvency Act; Mabe and Evans 2014 SA Merc LJ 651, where various fraudulent actions are taken by debtors and creditors to access the sequestration process are explained.

23 See amongst other cases Nedbank Limited v Malan; In re: Ex parte Application of Malan $2015 \mathrm{JOL} 33458$ (GP); Ex parte Erasmus 20151 SA 540 (GP); Nedbank Limited v Spencer 2015 ZAGPPHC 172 (3 March 2015); FirstRand Bank v Consumer Guardian 2014 ZAWCHC 27 (4 March 2014); Crafford v Crafford 2014 ZAWCHC 14 (13 February 2014); Ex parte Snooke 20145 SA 426 (FB); Ex parte Arntzen; Plumb on Plumbers v Lauderdale 20131 SA 60 (KZD); Ex parte Mark Shmukler-Tshiko and Emma Shmukler-Tshiko 2012 ZAGPJHC 209 (26 October 2012).

$24 \quad$ Bertelsmann et al Mars 74; Mabe 2017 THRHR 695.

25 Section 65 of the MCA; s 86 of the NCA; Nedbank Ltd $v$ National Credit Regulator 20113 SA 581 (SCA); Otto National Credit Act Explained para 30.9(c). 
indebted in terms of the debt review procedure in section 86 of the NCA 26 or they may apply for an administration order in terms of section 74 of the MCA. The debt review procedure is designed to assist over-indebted debtors by re-arranging their financial obligations under a credit agreement, with the objective of eventually settling the debt. ${ }^{27}$ Administration orders too are aimed at assisting over-indebted debtors by re-arranging their financial obligations, with the objective that the debtors' debt will ultimately be settled in full. ${ }^{28}$

Although debt review in terms of the NCA has no monetary limitation on the total outstanding debt, it applies only to debts that arose from credit agreements as defined by the NCA. ${ }^{29} \mathrm{~A}$ consumer who wishes to commence the debt review process must pay amongst other costs an application fee, ${ }^{30}$ a rejection fee if the application is rejected, ${ }^{31}$ and a restructuring fee less than or equal to the first instalment of the debt rearrangement plan. ${ }^{32}$ Once the debt review process is complete, a debt counsellor may recommend a magistrates' court order re-arranging the debtor's obligations. ${ }^{33}$ A debt review order will be granted only if it is believed that the debtor's financial affairs can be successfully re-arranged (eg, where the debtor receives a regular income or has assets to realise). ${ }^{34}$ If the court grants the order, the debtor will generally make monthly payments to a payment distribution agent ${ }^{35}$ that will distribute the amount among the credit providers. Debt counselling does not extinguish a credit provider's claim against a debtor but merely delays its enforcement ${ }^{36}$ and regulates the way and extent of the debtor's payments to creditors. ${ }^{37}$ During debt counselling

For a detailed discussion of debt review, see Kelly-Louw and Stoop Consumer Credit Regulation para 12.3; Scholtz et al Guide to the National Credit Act paras 11.3-11.4. Kelly-Louw and Stoop Consumer Credit Regulation in South Africa 324.

$\mathrm{Nel}$ Analysis of the Legislative Mechanisms fn 81, 21.

Section 4 read with s 8 of the NCA; Roestoff and Coetzee 2012 SA Merc LJ 68.

Section 86(3)(a), 86(4) of the NCA read with Schedule 2(2) of the National Credit Regulations, 2006 (NCA Regulations), Circular 6 of 2017 Interpretation of Section 71 of the NCA paras 1-6. See NCR 2018 http://www.ncr.org.za. The application fee currently set at R50 plus VAT.

31 The rejection fee is R300 excluding VAT.

32 The restructuring fee may not be more than $\mathrm{R} 6000$. Other costs include a maximum fee of R6 000 excluding VAT for joint applications, a monthly aftercare fee of $5 \%$ excluding VAT of the debt rearrangement instalment and a consent order fee of R750. See NCR 2011 http://www.ncr.org.za/pdfs/Guidelines/2011/ Debt_Counselling_Fee_Guidelines.pdf. Section $86(7)(c)(i i)(a a)-86(7)(c)(i i)(d d)$ for the methods of restructuring allowed by the NCA.

34 Sections 85-88 of the NCA; Van Heerden and Lötz 2010 THRHR 516.

35 Section $44 \mathrm{~A}$ of the NCA. 
a debtor is prohibited from obtaining any new credit, except as provided for in the NCA. ${ }^{38}$ An application for debt review does not constitute an act of insolvency in terms of the Insolvency Act, ${ }^{39}$ but it also does not per se preclude an application for sequestration. ${ }^{40}$

A consumer whose debts have been rearranged can be issued with a clearance certificate which will end his debt review but will not discharge his debts. ${ }^{41} \mathrm{~A}$ debtor can therefore be issued with a clearance certificate even if all his obligations under all the credit agreement that were subject to the debt re-arrangement have not been satisfied. ${ }^{42}$ This is in contrast to an administration order, where the debtor could remain under an administration order for ever. Debt review can also be terminated in terms of section 86(10) of the NCA. In such an instance the debtor will no longer be under debt review but his debts will not be discharged and he will have to continue paying as per the original credit agreement or as per the terms of the set aside debt review order.

The administration procedure is available to debtors whose debts do not exceed R50 000.43 Administration orders are granted by magistrates' courts to assist debtors in proceedings brought by those debtors who are not able to meet their financial obligations. ${ }^{44}$ Where a debtor has applied successfully for an administration order, an administrator is appointed to take control and manage the payment of debts due to creditors until all the listed creditors and administration costs are paid in full. ${ }^{45}$ The order usually requires the debtor to make regular payments to the administrator, who will, once all necessary expenses and determined remuneration, as per the tariff,

38 Section 88 of the NCA; Nedbank Ltd v National Credit Regulator 20113 SA 581 (SCA) 595 .

39 Section $8 \mathrm{~A}$ of the Insolvency Act which was inserted by the National Credit Amendment Act 19 of 2014 (hereafter the National Credit Amendment Act).

$40 \quad$ Investec Bank Ltd v Mutemeri 20101 SA 265 (GSJ) para 31; Naidoo v ABSA Bank 20104 SA 597 (SCA); Otto National Credit Act Explained para 58.

41 Section 71 of the NCA as amended by s 21 of the National Credit Amendment Act. Otto National Credit Act Explained para 11.4. For a detailed discussion of clearance certificates in terms of the NCA see Scholtz et al Guide to the National Credit Act para 11.4 .

42 A clearance certificate can be issued also if the debtor has demonstrated the financial ability to satisfy his future obligations in terms of the re-arranged order or that there are no arears on the re-arranged agreement. S 71 of the NCA read with reg 27 of the NCA Regulations; Circular 6 of 2017 Interpretation of Section 71 of the NCA paras 1-6. See NCR 2018 http://www.ncr.org.za and Otto National Credit Act Explained para 11.4. time and is currently set at R50 000 (GN R1411 in GG 19434 of 30 October 1998).

$44 \quad$ Paterson Eckard's Principles of Civil Procedure 318. 
have been deducted, pay the creditors from the balance. ${ }^{46} \mathrm{~A}$ debtor who wants to apply for an administration order must have a steady income. ${ }^{47}$ Debts that are payable by means of future instalments due in terms of an enforceable and existing contract, ${ }^{48}$ for example a mortgage agreement, are excluded from the administration order. 49

An administration order, like debt review, does not prevent the sequestration of the debtor's estate. ${ }^{50}$ The costs of the application for administration may be recovered from the first amounts received by the administrator from the debtor. ${ }^{51}$ The expenses and remuneration deductible by the administrator may usually not exceed $12.5 \%$ of the amount received from the debtor. ${ }^{52}$ As with debt review, the administration costs and administrator's fees unfortunately place an additional burden on a debtor's income, leaving less money available to distribute among the debtor's creditors. ${ }^{53}$

An administration order terminates only when the costs of the administration and all the listed creditors of the debtor have been paid in full. ${ }^{54}$ When the costs of the administration and all the creditors recorded in the administration order have been fully paid, the administrator is obliged to lodge a certificate to that effect with the clerk of the court, and send copies thereof to the debtor's creditors. ${ }^{55}$ There is no provision in the MCA that provides that the repayment of the debt must take place within a specific period of time, which means that many debtors may remain trapped by their debt. ${ }^{56}$ The intention of an administration order is to assist a debtor during a period of financial distress, and not to bind a debtor indefinitely. Regrettably it is the lack of any time limits linked to administration orders that undermine their intention. ${ }^{57}$ The administration procedure does not give

46 Theophilopoulos, Van Heerden and Boraine Fundamental Principles of Civil Procedure 396.

$47 \quad$ Fortuin v Various Creditors 20042 SA 570 (CPD) 575 (hereafter Fortuin v Various Creditors); Theophilopoulos, Van Heerden and Boraine Fundamental Principles of Civil Procedure 396.

48 Greig 2000 SALJ 622.

49 Section $74 \mathrm{C}(2)$ of the MCA; Fortuin $v$ Various Creditors 746.

$50 \quad$ Section 74R of the MCA; Shaban and Co (Pty) Ltd v Plank 19661 SA 59 (OPD) 59; $\mathrm{Nel}$ Analysis of the Legislative Mechanisms para 2.6.

51 Section 740 of the MCA.

52 Section 74L(2) of the MCA; African Bank Ltd v Weiner 20054 SA 363 (SCA) 373 (hereafter African Bank Ltd $v$ Weiner).

$53 \quad$ African Bank Ltd $v$ Weiner 367; Nel Analysis of the Legislative Mechanisms para 2.5.

$54 \quad$ Section 74U of the MCA; Kelly-Louw 2008 SA Merc LJ 222.

55 Section $74 \mathrm{U}$ of the MCA.

$56 \quad$ Nel Analysis of the Legislative Mechanisms para 2.6.

57 Boraine, Van Heerden and Roestoff 2012 De Jure 256, 265; African Bank Ltd v Jacobs 20063 SA 364 (CPD) 365; Ex parte August 20043 SA 268 (WLD) 271. 
the debtor a discharge of his debts at any stage, which is a serious disadvantage of this procedure. ${ }^{58}$

The sequestration process is designed to be to the benefit of the creditors of the debtor and to provide the debtor with a discharge of his debt. In contrast, both the administration process and the debt review process are designed specifically to assist over-indebted debtors to eventually settle their debt.

\section{Compositions under the South African insolvency law}

The South African insolvency law provides for two forms of compositions, namely common-law compositions and statutory compositions in terms of section 119 of the Insolvency Act. ${ }^{59}$ A common law compromise allows a debtor whose estate was provisionally sequestrated to avoid insolvency by entering into a compromise with his creditors. ${ }^{60}$ This type of compromise agreement is contractual and requires the approval of all the creditors to be binding. ${ }^{61}$ The advantage of a common law compromise is that once the agreement is approved the debtor will be released from his debts and any provisional order of sequestration will be discharged. ${ }^{62}$ The incentive for creditors is in receiving a higher dividend earlier than in sequestration and in saving on sequestration costs. ${ }^{63}$ However if one or more of the creditors fails to agree, the agreement falls away. ${ }^{64}$

If a debtor's estate has been sequestrated finally, a statutory compromise gives a debtor a chance to avoid the liquidation process, obtain control of all or some of his assets and shorten the period of insolvency. ${ }^{65} \mathrm{~A}$ statutory composition requires an acceptance by creditors whose votes amount to not less than a three-fourths majority in value and a three-fourths majority

58 Boraine, Van Heerden and Roestoff 2012 De Jure 254, 256; Kelly-Louw 2008 SA Merc LJ 222; Roestoff and Renke 2006 Obiter 99; Nel Analysis of the Legislative Mechanisms paras 2.6, 5.1.

$59 \quad$ For a detailed discussion see Bertelsmann et al Mars ch 24.

$60 \quad$ Mahomed v Lockhat Brothers \& Co Ltd 1944 AD 230 241; Sharrock, Van der Linde and Smith Hockly's Insolvency Law 203.

61 Prinsloo v Van Zyl 19671 SA 581 (T) 583 (hereafter Prinsloo v Van Zyl); Kopman v Benjamin 19511 SA 882 (W); Meskin et al Insolvency Law para 13.2; Bertelsmann et al Mars para 24.2; Sharrock, Van der Linde and Smith Hockly's Insolvency Law para 18.1. Bertelsmann et al Mars para 24.1; Sharrock, Van der Linde and Smith Hockly's Insolvency Law para 18.1.

63 Bertelsmann et al Mars para 24.1.

64 Bertelsmann et al Mars para 24.2.

65 Bertelsmann et al Mars para 24.1; Sharrock, Van der Linde and Smith Hockly's Insolvency Law 203. 
in number of all proved creditors' votes. ${ }^{66}$ The advantage of a statutory composition for the debtor is that it does not depend on the participation of all the creditors and the decision of the majority is binding. ${ }^{67}$ However, this form of compromise does not discharge the debts of the insolvent nor the sequestration order upon reaching the required majority. ${ }^{68}$ The insolvent remains unrehabilitated but can apply for early rehabilitation immediately after receiving a certificate from the Master of the acceptance of the offer of composition. ${ }^{69}$

\section{Bankruptcy in Kenya}

To initiate the alternatives to the bankruptcy procedures in the Kenyan Insolvency Act a debtor must be insolvent. ${ }^{70}$ It is therefore important to mention the requirements for entering the bankruptcy process in Kenya. A bankruptcy order can be awarded on application either by the debtor himself or by his creditors. In a debtor's application, the debtor must show that he is unable to pay his debts and his application for bankruptcy must be accompanied by a statement of his financial position. ${ }^{71}$ The court will not make the bankruptcy order if his financial statement is incorrect or incomplete. The court will also not make the order if it appears that, if the order is made, the total of the applicant's unsecured debts would be less than the small bankruptcy level ${ }^{72}$ and the value of the applicant's estate would be equal to or more than the minimum value. ${ }^{73}$

In a creditor's application, the creditor must show that the debtor is unable to pay the debt ${ }^{74}$ or has no reasonable prospect of being able to pay the

66 Section 119(7) of the Insolvency Act; Bertelsmann et al Mars para 24.5; Sharrock, Van der Linde and Smith Hockly's Insolvency Law para 18.3.

67 Bertelsmann et al Mars paras 24.1, 24.2.

68 Sharrock, Van der Linde and Smith Hockly's Insolvency Law 204.

69 Sections 119(7), 124 of the Insolvency Act; Sharrock, Van der Linde and Smith Hockly's Insolvency Law para 18.4.5.

70 See $\mathrm{s} 14$ of the new Act.

71 Section 32 of the new Act.

72 In terms s 33 of the Kenyan Insolvency Act and reg 19(b) of the Kenyan Insolvency Regulations, 2016 the small bankruptcy level is 100000 Kenyan shillings, which is equivalent to about R12 392 (conversion done through the currency converter found at Money Converter $2018 \mathrm{https}: / /$ themoneyconverter.com/ZAR/KES.aspx).

73 In terms of $\mathbf{S} 33$ of the Kenyan Insolvency Act and reg 19(a) of the Insolvency Regulations, 2016 the prescribed minimum value is 500000 Kenyan shillings which is equivalent to around R61 947 (conversion done through the currency converter found at Money Converter 2018 https://themoneyconverter.com/ZAR/KES.aspx).

74 In order to show this requirement, the creditor must indicate that the amount of the debt was due and despite serving the debtor with a demand requiring payment of the debt, the debtor did not make payment. Section 17(3)(a) of the new Act. 
debt. ${ }^{75}$ In addition, the creditor must prove that the debt is for a liquidated amount, it exceeds the bankruptcy level, ${ }^{76}$ and lastly there is no outstanding application to set aside a statutory demand in respect of the debt. ${ }^{77} \mathrm{~A}$ bankruptcy order will not be made unless these requirements are met. ${ }^{78}$

\subsection{Alternatives to bankruptcy under the new Insolvency Act}

Prior to the enactment of the new Insolvency Act in Kenya, the insolvency of natural persons was dealt with under the old Bankruptcy Act while corporate insolvency was dealt with under the winding-up provisions of the Companies Act. Like the South African Insolvency Act, the old Kenyan Bankruptcy Act also did not provide for alternatives to bankruptcy. The latter Act did, however, contain a provision on schemes of arrangement and compositions, under section 18. The acceptance of the proposal for a composition to satisfy his debts or a scheme of arrangement of his affairs with his creditors did not release any person who under the old Bankruptcy Act would not be released by an order of discharge, had the debtor been declared bankrupt. ${ }^{79}$ In terms of the old Bankruptcy Act there was no automatic discharge period. A bankrupt had to apply to the court for a discharge of debt and the court had the sole discretion to decide whether to discharge the bankrupt. ${ }^{80}$

It is submitted that Kenya's new Insolvency Act, contrary to the old Bankruptcy Act, was drafted with an intention of meeting the needs not only of creditors but also of debtors, as envisaged by the World Bank Report. This can be seen in its preamble, which explains its purpose to include among other things:

75 In order to show this requirement, the creditor must indicate that the amount of the debt was not immediately payable and despite serving the debtor with a demand requiring an establishment by the debtor to the satisfaction of the creditor that there is a reasonable prospect that he will be able to pay the debt, the debtor did not comply. Section 17(4) of the new Act.

76 In terms of reg 3 of the Insolvency Regulations, 2016, the prescribed bankruptcy level is 250000 shillings, which is equivalent to R30 926 depending on the exchange rate (conversion done through the currency converter found at Money Converter $2018 \mathrm{https}: / /$ themoneyconverter.com/ZAR/KES.aspx).

77 Section 17 of the new Act.

78 Sections 25, 32 of the new Act.

79 Section 18(20) of the old Bankruptcy Act of Kenya.

80 Section 29 of the old Bankruptcy Act of Kenya. Considering the additional cost implication associated with making an application to an already overburdened bankrupt, it is submitted that this could have had the possibility of a bankrupt's being bankrupt for life if he did not apply for bankruptcy. 
to provide for and to regulate the bankruptcy of natural persons; to provide alternative procedures to bankruptcy that will enable the affairs of insolvent natural persons to be managed for the benefit of their creditors;

Furthermore, the new Insolvency Act also introduced debtor-friendly interventions such as an automatic discharge after three years from the date of lodgement of the statement of financial affairs, or earlier. ${ }^{81}$ These new alternatives to bankruptcy procedures provided for in section 14 of the new Act will be discussed next.

\subsection{Individual Voluntary Arrangements (IVA)}

The Individual Voluntary Arrangements (IVA) replaced the old compositions and schemes of arrangement contained in section 18 of the old Bankruptcy Act. With IVA a debtor who wants to make a proposal to his creditors makes an interim application to the court instead of to the Official Receiver (OR), 82 and the court has the power to order a meeting that convenes the creditors. If the debtor is an undischarged bankrupt, a notice must first be given to the OR before the interim application ${ }^{83}$ and the application may not be made while a bankruptcy application by the debtor is pending. ${ }^{84}$ While the interim application is pending, the court may prohibit the sale of the debtor's property and may stay any action, execution or other legal process against the property or person of the debtor. ${ }^{85}$ The proposal must provide for a person to be a supervisor of the voluntary arrangement. ${ }^{86}$ The court may grant an order to convene the creditors' meeting in the view that it will help facilitate the consideration and implementation of the proposal. ${ }^{87}$ At the

81 Sections 254,258 of the new Act.

Section 304 of the Kenyan Insolvency Act. In the old Bankruptcy Act, s 18 allowed a debtor who intended to make a proposal to submit such a proposal to the Official Receiver (OR) within four days of submitting his statement of affairs.

83 Section 304(5) of the new Act.

84 Section 304(6). To initiate the alternatives to the bankruptcy procedures in the new Act, a debtor must be insolvent. See s 14 of the new Act.

85 Sections 305(1)(b) and 305(2) of the new Act. In addition, once the interim order is made, a bankruptcy application relating to the debtor may not be proceeded with. S 306(7).

86 Section 304(2). In terms of s 33(2)(b), the same insolvency practitioner who is appointed during the hearing of a debtor's application to prepare a report into the debtor's financial circumstances is used as a supervisor in an IVA application.

87 Section 306(2) of the new Act. The court will make the order only if it is satisfied that on the day of making the application the debtor was an undischarged bankrupt or able to make an application for his own bankruptcy; that in the last 12 months no similar application had been made by the debtor, and that the supervisor enlisted is willing to act in relation to the proposal. S 306(1). 
meeting of creditors, the proposal will be approved by a majority of votes in number and in value of the creditors present. ${ }^{88}$

The court may order the approval of the proposal or any other order it deems fit, provided it is in the best interests of the debtor and creditors. ${ }^{89}$ The court may approve the proposal even though preferential and unsecured creditors have not approved, provided that it was approved by a majority of the secured creditors, it did not discriminate against dissenting groups, and preferential creditors' interest were respected over unsecured creditors' interests. ${ }^{90}$

Once approved, the proposal becomes a voluntary arrangement and binds the debtor and creditors and the provisional supervisor becomes the supervisor of the arrangement. ${ }^{91}$ Approval dismisses any bankruptcy applications against the debtor that were pending or stayed. ${ }^{92}$

\subsection{Expedited procedure}

The expedited procedures apply when an undischarged bankrupt wants to make a proposal for an IVA but an interim application has not been made to the court and the OR has been indicated as the supervisor in the proposal. ${ }^{93}$ After the debtor has provided the OR with the proposal and his statement of affairs ${ }^{94}$ and the OR is satisfied that the proposal has a reasonable prospect of approval, the OR arranges a meeting of creditors. ${ }^{95}$ Soon after the creditors' decision to approve or reject the proposal, the supervisor (OR) has to report to the court. ${ }^{96}$ If approved, the proposal becomes a voluntary arrangement and is binding on all creditors and the debtor. ${ }^{97}$

The OR may thereafter apply to the court for an annulment of the bankruptcy order, but such an application may not be made during the

88 Section 311(2) of the new Act.

89 Section 311(7) of the new Act.

90 Section 311(8) of the new Act.

91 Section 312 of the new Act.

92 Section 312(7) of the new Act.

93 Section 316(1) of the new Act. See fn 85 above on the effect of an interim order application.

94 This requirement seems unnecessary, taking into account that the trustee of the bankrupt estate should already have the debtor's statement of affairs, unless they have changed.

95 Section 316(3) of the new Act.

96 Section 317 of the new Act.

97 Section 318 of the new Act 
period in which the arrangement may be challenged in court ${ }^{98}$ and unless there are compelling reasons not to do so. ${ }^{99}$ The court may direct the debtor to act in a manner that will facilitate the implementation of the voluntary arrangement ${ }^{100}$ but the court may revoke the arrangement if it unfairly affects creditors or if there is a material irregularity. ${ }^{101}$

It is regarded as criminal conduct for a debtor to make false, misleading representation, act fraudulently or omit to do any action for the purpose of obtaining approval of the voluntary arrangement. ${ }^{102} \mathrm{~A}$ guilty debtor is liable to a fine not exceeding two million shillings ${ }^{103}$ or to imprisonment of not more than five years. ${ }^{104}$

\subsection{Summary Instalment Order (SIO)}

A Summary Instalment Order (SIO) is an order from the OR, upon application by a debtor or creditor with the debtor's consent, directing a debtor to pay his debts in full or in instalments, ${ }^{105}$ in the manner prescribed by the insolvency regulations. ${ }^{106}$ In addition, the OR may make orders regarding the debtor's future income or the disposal of his assets. ${ }^{107}$ The OR may refuse the application if it is not satisfied that the application:

- $\quad$ was made in the form prescribed by the insolvency regulations;

- does not state that the debtor will make payment in full;

- does not indicate the total number of instalments to be made weekly or monthly;

- does not indicate the total earnings of the debtor;

- does not indicate whether the debts are secured; and

\footnotetext{
98 Section 318(3) of the new Act.

99 Section 318(4) of the new Act.

100 Section 319 (4) of the new Act.

101 Section 320 of the new Act.

102 Section 321(1) of the new Act.

103 This is equivalent to about R246 277 (conversion done through the currency $\begin{array}{llll}\text { converter found } & & \\ \end{array}$ https://themoneyconverter.com/ZAR/KES.aspx).

104 Section 321(4) of the new Act.

105 Sections 323, 324 of the new Act.

106 Section 334 of the new Act.

107 Sections 327, 327(c), 340 of the new Act. Such an order may also include an instruction to the supervisor to direct the debtor's employer to pay all or part of the debtor's income to the supervisor.
} 
- does not indicate the name and address of the supervisor of the proposal. In such a case, the debtor will be required to provide reasons why a supervisor is not necessary. ${ }^{108}$

The OR may make the order if it is satisfied that the debtor's total assets do not exceed five hundred thousand shillings, as prescribed by the insolvency regulations $^{109}$ and that the debtor is unable to make payment immediately. ${ }^{110}$ However, the OR must first provide the creditors with an opportunity to make representation on the matter. ${ }^{111} \mathrm{An} \mathrm{SIO}$ is ineffective if it does not mention the appointment of a suitable and willing supervisor to ensure the debtor's compliance with the order. ${ }^{112}$ This is because the supervisor is responsible for ensuring the debtor's compliance with the orders made by the OR. ${ }^{113}$ For this service, the supervisor may charge remuneration provided that it does not exceed $7 \%$ of the value of the assets of the debtor that are recovered by the supervisor. ${ }^{114}$ The OR may omit the appointment of a supervisor if it deems it appropriate, however, and in such a case the debtor and the OR will act as supervisors. ${ }^{115}$

An order made by the OR is effective for a maximum period of three years, unless on the existence of special circumstances and on acceptance by the supervisor the period is extended to five years. ${ }^{116}$ The debtor, creditor or supervisor may at any time apply to the OR to change or to discharge the SIO. ${ }^{117}$ The OR may order the cancellation of the SIO, however, should the debtor fail to make instalments in the prescribed manner.

An SIO has the effect of preventing and staying all proceedings against a debtor in respect of his bankruptcy unless the debtor defaults payment or the OR approves. ${ }^{118}$ The supervisor must send out a notice of the SIO to

\footnotetext{
108 Sections 324, 325(2) of the new Act.

109 See reg 51 of the Insolvency Regulations, 2016. Five hundred thousand shillings is equivalent to $\mathrm{R} 61526$ depending on the exchange rate.

110 Section 326(1) of the new Act.

111 Section 326(2) of the new Act.

112 Section 328 of the new Act.

113 Section 329 of the new Act. The role of the supervisor is so important that it is punishable by a fine or termination if the supervisor does not provide the OR with documents relating to the debtor's conduct and administration of his estate within 7 days of the notice to do so.

114 Section 329(2) of the new Act; reg 69 of the Insolvency Regulations, 2016.

115 Sections 328(2)-328(3) of the new Act.

116 Section 332 of the new Act.

117 Section 333 of the new Act.

118 Section 335(2) of the new Act.
} 
every proved creditor whose name appears on the debtor's application ${ }^{119}$ and those creditors shall be included in the administration of the debtor's estate under the SIO. ${ }^{120}$ A creditor who proves a claim after the SIO has been made may elect to be included in the administration of the debtor's estate. ${ }^{121}$ However, such a creditor may be paid a dividend only after the earlier creditors have been paid. ${ }^{122}$

A debtor who fails to pay amounts due under an SIO is presumed to have been able to pay that amount from the date of the order but to have neglected to pay. Should the debtor fail to pay, all stayed proceedings resume and the supervisor is required to notify the OR. ${ }^{123} \mathrm{~A}$ debtor who is the subject of a SIO commits an offence if he obtains credit of more than one hundred thousand shillings ${ }^{124}$ before all creditors have been paid, unless he has informed the credit provider that he was subject to a SIO. ${ }^{125}$ Any debtor guilty of this offence is liable to a fine not exceeding one million shillings ${ }^{126}$ or to imprisonment of not more than twelve months or both. ${ }^{127}$

\subsection{The no asset procedure}

The no asset procedure provides a debtor with no realisable assets with an alternative to bankruptcy. ${ }^{128} \mathrm{~A}$ debtor may commence this procedure by making an application to the OR in the prescribed form, which requires a statement of the debtor's financial position. ${ }^{129}$ The application may be rejected if the statement is incorrect. ${ }^{130}$

For the debtor's application to succeed the OR must be satisfied that a debtor has no realisable assets, ${ }^{131}$ he has not been previously admitted to

119 Section 336 of the new Act. The supervisor shall be liable to a fine should the notices not be sent, without reasonable excuse.

120 Section 339 of the new Act.

121 Section 339(4) of the new Act.

122 Section 339(5) of the new Act.

123 Section 341 of the new Act.

124 This is equivalent to about R12 975 (conversion done through the currency converter found at Money Converter 2018 https://themoneyconverter.com/ZAR/KES.aspx).

125 Section 342 of the new Act.

126 This is equivalent to about R129 975 (conversion done through the currency converter found at Money Converter $2018 \mathrm{https}: / /$ themoneyconverter.com/ZAR/ KES.aspx).

127 Section 342(3) of the new Act.

128 Section 343 of the new Act.

129 Section 344(2) of the new Act.

130 Section 344(3) of the new Act.

131 These assets do not include assets which the bankrupt is allowed to choose to keep as his own property in terms of $\mathrm{s} 161$ of the new Act, which include among other things the bankrupt's necessary tools of trade, necessary household furniture and a motor vehicle. Realisable assets do include assets that may be recoverable by the 
the procedure or been previously bankrupt, his total debts are not less than one hundred thousand shillings and not more than four million shillings, ${ }^{132}$ and that he does not have the means to repay those debts. ${ }^{133} \mathrm{He}$ may be disqualified, however, if he concealed assets with an intention to defraud his creditors and engaged in conduct that would amount to an offence if he were to be declared bankrupt. He would further be disqualified if he incurred a debt knowing that he did not have the means to repay it or if the OR is satisfied on reasonable grounds that a creditor intends to apply for the debtor to be declared bankrupt and it is likely that bankruptcy would result in a materially better outcome for the creditor, than the no-asset procedure. ${ }^{134}$ This disqualification appears contradictory to the main purpose of the no asset procedure, which is to provide an alternative to bankruptcy to debtors with no realisable assets. Secondly, if a debtor has no realisable assets, how can bankruptcy result in a materially better outcome for creditors than the no-asset procedure?

As soon as the application is received, the OR must send a summary of the debtor's assets and liabilities to all known creditors. ${ }^{135}$ Making the application prohibits the debtor from obtaining credit of more than ten thousand shillings ${ }^{136}$ without first informing the credit provider of the noasset procedure application. ${ }^{137}$ A contravening debtor commits an offence punishable with a fine of not more than five hundred thousand shillings ${ }^{138}$ or to imprisonment of not more than six months. ${ }^{139}$ Taking into account the circumstances of the debtor under the no-asset procedure, it is submitted that the debtor should be completely prohibited from making more debt upon making the application.

On the debtor's admission to the procedure, the OR will send a notice to the debtor and each creditor and will publish the notice in the prescribed

OR (such as gifted assets), however, if the debtor were to be declared bankrupt on the date of application for entry to the no asset procedure. S 345(2) of the new Act. Not less than about R12 312 but not more than R519 012 (conversions done through the currency converter found at Money Converter 2018 https://themoneyconverter.com/ZAR/KES.aspx).

133 Section 345 of the new Act.

134 Section 346 of the new Act.

135 Section 347 of the new Act.

136 This is equivalent to about R1 283 (conversion done through the currency converter found at Money Converter 2018 https://themoneyconverter.com/ZAR/KES.aspx).

137 Section 348 of the new Act.

138 This is equivalent to about R62, 405 (conversion done through the currency converter found at Money Converter 2018 https://the moneyconverter.com/ZAR/KES.aspx). 
manner. ${ }^{140}$ On the debtor's admission, his creditors are prohibited from enforcing debts against the debtor that were owed to the creditor at the time the debtor applied for the no-asset procedure and which would be a provable debt if the debtor would be declared bankrupt. ${ }^{141}$ Certain debts, however, remain enforceable. ${ }^{142}$ The debtor is also prohibited upon admission from obtaining credit of more than one hundred thousand shillings ${ }^{143}$ from a credit provider without informing the provider and is punishable in such an event with a fine of one million shilling ${ }^{144}$ or imprisonment of not exceeding 12 months or to both. ${ }^{145}$

The no-asset procedure commences from the date of admission. Thereafter the debtor's debts (except excluded debts) ${ }^{146}$ are automatically discharged after twelve months, unless the period is extended for a period not exceeding 35 days after the end of the twelve-month period. ${ }^{147}$ Once discharged, the debts that became unenforceable are cancelled and the debtor is no longer required to pay any part of the debts, including penalties and interests that may have accrued. ${ }^{148}$ This does not apply, however, to debts incurred fraudulently. ${ }^{149}$ Participation in the procedure may also be terminated earlier, either by the $\mathrm{OR}^{150}$ by a creditor ${ }^{151}$ or by a debtor

\footnotetext{
140 Section 349 of the new Act.

141 Section 351(1) of the new Act.

142 Debts that remain enforceable include amounts payable under a court order made under the Matrimonial Causes Act (Cap 152 of the Laws of Kenya) (hereafter Matrimonial Causes Act), amounts payable under the Children Act (Cap 8 of the Laws of Kenya) (hereafter Children Act) and amounts owed in respect of a loan to secure the education of a dependent child or step-child of the debtor. S 351(2) of the new Act.

143 This is equivalent to about R12, 481 (conversion done through the currency converter found at Money Converter 2018 https://themoney converter.com/ZAR/KES.aspx).

144 This is equivalent to about R124, 810 (conversion done through the currency converter found at Money Converter 2018 https:// themoneyconverter.com/ZAR/KES.aspx).

145 The debtor can use the fact that the credit provider was aware of the no-asset procedure, as a defence. S 353 of the new Act.

146 Debts that remain enforceable include amounts payable under a court order made under the Matrimonial Causes Act, amounts payable under the Children Act and amounts owed in respect of a loan to secure the education of a dependent child or step-child of the debtor. S 351(2) of the new Act.

147 Section 359(1) of the new Act. The S 359 discharge does not release a debtor's business partners and others. $S 361$ of the new Act.

148 Section 360 of the new Act.

149 Those debts incur similar effects to termination of the procedure by the OR. Section 360(2) of the new Act.

150 The OR may terminate the procedure where a debtor was wrongly admitted (the debtor concealed assets) or where the debtor's financial circumstances have changed. See s 355 of the new Act.

151 A creditor may apply for the termination of the debtor's participation on the grounds that the debtor did not meet the criteria for admission or that there are reasonable
} 
applying for his own bankruptcy, ${ }^{152}$ or by a creditor's application for the debtor's bankruptcy. ${ }^{153}$ Upon early termination, the debtor's debts become enforceable and he becomes liable to pay any penalties and interest that may have accrued. ${ }^{154}$

\section{Analysis}

As mentioned earlier, this article seeks to answer the question whether the current alternatives available in South Africa to the sequestration process allow debtors in different financial positions to obtain a discharge. The first investigation was whether the alternatives available in South Africa to the sequestration processes provide debtors in different financial positions with a discharge of debts.

In South Africa only applicants who are able to show that sequestration will be to the benefit of creditors can access the sequestration process. ${ }^{155}$ If they are unable to meet this requirement, sequestration will not be possible and debtors, depending on their situation and the debts involved, can make use of debt review in terms of the NCA or administration orders in terms of the MCA. Due to the different nature of the debts governed by each of these two mechanisms, the same debtor may be under debt review and administration simultaneously. However, both debt review and administration orders do not provide for a discharge of debt. They provide for debt restructuring only, in order to eventually satisfy creditors' claims. The cost implications ${ }^{156}$ of debt review and the fact that it applies only to credit agreements falling within the scope of the NCA limit its suitability to

grounds for the OR to conclude that the debtor can be disqualified. Ss 354(d), 358 of the new Act.

152 Section 354(c) of the new Act.

153 Creditors who can apply for a debtor's bankruptcy include those creditors whose debts remain enforceable under s 351(2) of the new Act. See fn 138 and 142 above.

154 This does not occur if the no asset procedure is terminated by a discharge under $\mathrm{S}$ 359 of the new Act. S 357(2) of the new Act.

155 Evans suggests that the advantage requirement distinguishes between rich and poor debtors since only rich debtors can show sufficient assets to pay for the costs of sequestration. As one can be too poor to be declared insolvent in South Africa, poor debtors are excluded from the sequestration procedure and the eventual discharge of their debts. Coetzee further explains this by indicating that the advantage requirement separates those debtors who can access the sequestration process from those who cannot, and ultimately makes obtaining debt relief to no income and no assets (NINA) debtors difficult. See Evans 2002 IIR 34; Rochelle 1996 TSAR 319; Coetzee Comparative Reappraisal of Debt Relief Measures 9; Mabe 2017 THRHR 695.

156 The debt re-arrangement plan must be viable. See Seyffert $v$ Firstrand Bank Ltd t/a First National Bank 20126 SA 581 (SCA) para 13; Roestoff and Coetzee 2012 SA Merc LJ 68. 
certain debtors. Administration orders are also not a favourite because they are also available only to debtors whose creditor's claims do not exceed R50 000, and they may also be expensive, taking into account the fact that the administration will pay creditors only after all the necessary expenses and determined remuneration have been deducted.

If the sequestration process has already commenced, South African debtors may enter into a compromise with their creditors. Although the common-law compromise releases the debtor from his debts and discharges any provisional order of sequestration, it requires a buy-in by all the creditors, which may be difficult to attain. The statutory compromise, on the other hand, does not discharge the sequestration order or debts, although the debtor may apply for early rehabilitation after receiving a certificate from the Master of the acceptance of the offer of composition. ${ }^{157}$

If the debt intervention in the Draft Bill is implemented in a future National Credit Amendment Act it may provide an alternative to the sequestration process that provides for a discharge of debts. However, it would still apply to certain debtors ${ }^{158}$ and, like administration orders, exclude the group of debtors with debts above R50 000. Like debt review, debtors whose debts did not arise from a credit agreement would also be excluded. A debtor who seeks a discharge of debts and who cannot meet the advantage requirement for a sequestration order would be in the same position with or without the debt intervention process in the Draft Bill.

The Kenyan Insolvency Act does not have a requirement equivalent to the South African requirement that the sequestration will be to the benefit of creditors. Instead, in Kenya a bankruptcy order will be awarded if it is shown ${ }^{159}$ or appears to be shown that a debtor is unable to pay his debts or has no reasonable prospect of being able to pay his debts. ${ }^{160}$ Further, a Court in Kenya will not give a bankruptcy order if in a debtor's application it will reduce the value of the applicant's unsecured debts to less than R12 $392^{161}$ and the value of the applicant's estate would be equal or more than

157 Section 124(1) of the Insolvency Act.

158 See fn 151 above, where Evans makes a distinction between poor debtors and rich debtors and explains that in South Africa poor debtors are excluded from the sequestration procedure and the eventual discharge of their debts. Likewise the debt intervention in the Draft Bill and administration orders applies only to poor debtors but excludes debtors who are not poor enough because their debts are above R50 000 (the poor and the not poor enough).

159 This requirement is for a debtor's application. S 31 of the new Act.

160 This requirement is for a creditor's application. $S 17$ of the new Act.

161 Which is the small bankruptcy level in Kenya. S 33 of the Kenyan Insolvency Act; reg 19 of the Insolvency Regulations, 2016. 
R61 $947^{162}$ and in a creditor's application the debt is less than R30 $926 .{ }^{163}$ This appears to mean that if in a bankruptcy initiated by a debtor, bankruptcy will result in a debtor's debts being less than the small bankruptcy amount of R12 392 and his assets being equal to or more or less than the minimum amount of R61 947, such a debtors' application will be dismissed and such a debtor will not be able to access the bankruptcy procedure. If this is correct, it would also mean that if a debtor's debts are less than the bankruptcy level of R30 926 a creditor will not apply for such a debtor's bankruptcy. Consequently, such a debtor will not be able to benefit from the discharge of debts that bankruptcy eventually provides on rehabilitation. This puts such a debtor in the same position as the South African debtor who is unable to show a benefit to creditors. Unlike the South African debtor, however, the Kenyan debtor has some incentives. Firstly, his debts will automatically be discharged after three years of lodging his statement of financial affairs. Secondly, he can also make use of one of the alternatives to bankruptcy procedures provided by the new Act, ${ }^{164}$ where applicable, which are absent from the South African Insolvency Act. Despite the automatic discharge after three years incentive, the Kenyan Insolvency Act does not appear to have a requirement or process that will curb desperate debtors who may want to use fraudulent ${ }^{165}$ means to access the bankruptcy process to eventually obtain automatic discharge after three years.

The question that begs an answer now is whether the alternatives to the bankruptcy procedures in the Kenyan Insolvency Act really provide an alternative to bankruptcy that provides for a discharge of the debts of debtors with small debts and small assets and debtors with big debts but with small assets. Or do they provide an alternative that only suspends or postpones bankruptcy but not necessarily an alternative that leads to a discharge of debts. As already mentioned, Kenya introduced a wide range of alternatives to the bankruptcy procedure, which at face value appear to achieve this purpose. As indicated, these include the IVA, the expedited procedure, the SIO and the no asset procedure.

\footnotetext{
162 Which is the minimum value. See s 33 of the Kenyan Insolvency Act; reg 19 of the Insolvency Regulations, 2016.

163 Which is the bankruptcy level. See reg 3 of the Insolvency Regulations, 2016.

164 Section 33(1)(d) read with s 34(2) of the new Act, which provides that a court will not make a bankruptcy order if it appears that it would be necessary to appoint an insolvency practitioner to prepare a proposal for a voluntary arrangement.

165 That may include debtors who deliberately incur debts in order to obtain the discharge.
} 


\subsection{The IVA}

Although the IVA replaced the schemes of arrangement and compositions under section 18 of the old Kenyan Bankruptcy Act, it is submitted that the IVA is not a new procedure but an improvement of the section 18 schemes of arrangement and compositions. With the section 18 procedures, a threefourths majority in number and in value was required for acceptance of the proposal by creditors who had proved their claims, before approval by the court. The IVA, on the other hand, requires a majority of votes in number and in value of the creditors present before approval. With an IVA the court will grant an order to convene a creditors' meeting only if it will help facilitate the consideration and implementation of the proposal; and in approving the proposal, the court will consider the interest of the debtor and creditors. However, while section 18(20) of the old Bankruptcy Act explicitly indicated that it did not release any person from his debts who could not be released by an order of discharge, the new Act does not mention the release of the debtor from his debts; only, that pending or stayed bankruptcy applications are dismissed. ${ }^{166}$ It appears, then, that although the court may approve an IVA and make any order it deems fit, taking account the interest of the debtor and creditors, the approval still does not provide the debtor with a discharge of his debts. It leads only to the dismissal of bankruptcy applications.

The outcome of the IVA is similar to those of both the South African common law compromise and the South African statutory compromise, however. Like the common law compromise, the IVA releases the debtor from any bankruptcy applications and the debtor is therefore able to avoid the bankruptcy procedure and its costs. ${ }^{167}$ Like the common law compromise, ${ }^{168}$ a creditor may still challenge the decision to approve the proposal, and in such a case the court may revoke the approval. ${ }^{169}$

The IVA is also similar to the statutory compromise in that it appears that it does not discharge the debtor from the debt itself. The debtor has to pay his debt according to the voluntary arrangement, under supervision. ${ }^{170}$ If the debt amount has not been paid at the end of the arrangement, the Kenyan

\footnotetext{
166 Section 312(7) of the new Act.

167 Sharrock, Van der Linde and Smith Hockly's Insolvency Law 203, s 312(7) of the Kenyan Insolvency Act.

168 With the common law compromise, a dissenting creditor may still apply for the sequestration of the debtor's estate and nullify the effect of the agreement. See Sharrock, Van der Linde and Smith Hockly's Insolvency Law para 18.1; Prinsloo $v$ Van Zyl 583.

169 Section 314(4) of the Kenyan Insolvency Act.

170 Sections $312(3), 315$ of the new Act.
} 
Insolvency Act provides that the debtor will then become liable for the outstanding amount, payable to that specific creditor. ${ }^{171}$

\subsection{The expedited procedure}

The expedited procedure appears to be an accelerated IVA, except that the meeting of creditors is instead arranged by the supervisor (OR). ${ }^{172}$ It appears, however, that this procedure is stricter than the IVA because if the proposal is accepted by the creditors and approved by the court, pending or stayed bankruptcy applications are not dismissed automatically as is the case with IVA. Instead, an application may be made by the OR to annul the bankruptcy order. Further, the IVA has heavy sanctions for committing fraudulent actions in order to obtain approval of the voluntary arrangement. ${ }^{173}$ Like the IVA, the expedited procedure does not provide for the discharge of debts.

\subsection{The SIO}

The SIO is similar to both the South African NCA's debt review process and the magistrates' court administration order. Like debt review, the $\mathrm{SIO}$ is an order instructing the debtor to pay his debts in instalments. The SIO requires that the instalments be paid in the manner prescribed by the Insolvency Regulations ${ }^{174}$ and that the OR must provide creditors with an opportunity to make representations before making the order. The OR is also allowed to make other orders. ${ }^{175}$ With debt review, the court grants orders only in accordance with the terms of the debt counsellor's recommendations, and as permitted by the NCA. ${ }^{176}$

A SIO does not discharge debts, but unlike debt review, which only postpones debt enforcement and does not protect a debtor from sequestration applications, a SIO suspends proceedings against the debtor but also suspends bankruptcy applications against the debtor. ${ }^{177}$ A SIO may be discharged, changed or cancelled on application by the debtor, creditor

\footnotetext{
171 Section 312(4) of the new Act.

172 In the expedited procedure, the OR is appointed as the supervisor.

173 A guilty debtor is liable to a fine not exceeding R259 506 or to imprisonment of not more than five years. S 321(4) of the new Act.

174 Such regulations include amongst others that payment to creditors must be made every four months, unless the SIO provides otherwise. See regs 52(2) and 71 of the Insolvency Regulations, 2016.

175 Section 327 of the new Act.

176 Section 86(7)(c) of the NCA, for the recommendations that the debt counsellor may request the Magistrate's Court.

177 All suspended proceedings resume however, should the debtor fail to make payments. See s 335(2) of the new Act.
} 
or supervisor, but generally it is effective for a maximum period of three years, unless extended to five years. ${ }^{178}$

Whereas debt review prevents a debtor under debt review from entering into any new credit agreements, except as permitted by the NCA, a debtor who is the subject of a SIO is only prohibited from obtaining credit of more than R12 975. If the debtor informed a credit provider before getting credit above the credit limit that he is the subject of a SIO, the debtor would not have committed an offence. ${ }^{179}$

In debt review the supervisor in a SIO, like a debt counsellor, is permitted to receive remuneration. ${ }^{180}$ However, the OR may decide not to appoint a supervisor where necessary and thereby save on supervisor costs, while the appointment of a debt counsellor is not optional. It is submitted that saving costs is important, taking into account the fact that a SIO is granted to debtors who have assets valued below R61 526 .

Debt review, administration orders ${ }^{181}$ and SIOs are all expensive, but with debt review there is no monetary limit on the total outstanding debt or the debtor's total number of assets for a debtor to apply for debt review. In this respect, debt review appears better. At the crux of debt review, however, is the fact that it must be possible to re-arrange the debt, the debtor must have a steady income, and it applies to credit agreements only, whereas SIO applies to all types of agreements.

Even though the proposed debt interventions in the Draft Bill provide for the discharge of debt for certain debtors, like debt review they can be accessed only by debtors whose debts arose from credit agreements, and the applicant's debt must not be more than R50 000. This is similar to a South African administration order, which is available to debtors whose claims do not exceed R50 000 only, and to the SIO, which is available to debtors whose total assets do not exceed R61 526 only. This limitation leaves those

\footnotetext{
178 Section 332 of the new Act.

179 Any debtor guilty of this offence is liable to a fine not exceeding one million shillings $(122976,36)$ or to imprisonment of not more than twelve months or both.

180 The remuneration must not be more than $7 \%$ of the debtor's assets recovered by the supervisor. See s 329(2) of the new Act and reg 69 of the Insolvency Regulations, 2016.

181 Only once the necessary expenses have been paid will the administrator pay creditors. See para 3 of this article.
} 
debtors who cannot meet these monetary limits without an alternative to bankruptcy. ${ }^{182}$

\subsection{The no asset procedure}

The no asset procedure could be the true alternative to the bankruptcy procedure for debtors who fall outside the bankruptcy requirements. To participate, a debtor must show that he has no realisable assets, his debts are between R12 975 and R519 012, and he has no means to pay those debts. On his admission to the procedure, his creditors cannot enforce their claims nor apply for the debtor's bankruptcy, and upon his discharge after 12 months from admission, all his debts are discharged including all accrued penalties. ${ }^{183}$ This comes at a high price, however, because there are harsh penalties for debtors who contravene the prohibitions. ${ }^{184}$ The penalties become even heavier for debtors who obtain credit on admission to the procedure. ${ }^{185}$ In addition, if the procedure is terminated earlier as a result of fraudulent actions by the debtor or because of a bankruptcy application by a debtor or a bankruptcy application by a creditor whose debts remain enforceable as specified in section $351(2)^{186}$ of the new Act, all the debtor's debts become enforceable, including any penalties and interests that may have accrued. ${ }^{187}$

In South African law there is no procedure that provides a discharge to debtors with no assets and who have debts above R50 000. The debt intervention in the Draft Bill, as indicated, applies to certain debtors only. In an attempt to allow debtors in all financial positions to become economically capable through a discharge, South African lawmakers should consider including an intervention similar to the Kenyan no-asset procedure in the Insolvency Act. Unlike the Kenyan no asset procedure, however, the South African procedure should prohibit a debtor who has been admitted to the process from obtaining more credit altogether, and not only where the

\footnotetext{
182 However, these debtors can apply to participate in the no asset procedure if they can show that they have no realisable assets. See para 5.5 in this paper.

183 This does not apply to debts incurred fraudulently.

184 The debtor is prohibited from getting credit of more than R1 283 when he makes the application. The offence is punishable with a fine of more than R62,405 or to imprisonment of more than six months. S 348 of the new Act.

185 The debtor is prohibited from getting credit of more than R12,481 on admission to the procedure. The offence is punishable with a fine of more than $\mathrm{R} 124,810$ or to imprisonment of not exceeding twelve months or both. S 353 of the new Act.

186 Debts that remain enforceable include amounts payable under a court order made under the Matrimonial Causes Act, amounts payable under the Children Act and amounts owed in respect of a loan to secure the education of a dependent child or step-child of the debtor. S 351(2) of the new Act. Section 357 of the new Act.
} 
debtor has not informed the credit provider. The penalty for contravening such a prohibition should be more stringent, to serve as a deterrent.

Lastly, a debtor should not be disqualified from admission into the process because it appears that a creditor intends to apply for the debtor to be declared bankrupt. The aim of the no asset procedure is to avoid bankruptcy. Secondly a debtor who is a candidate for the procedure would not be a good candidate for bankruptcy, because he has no realisable assets which could benefit creditors.

\section{A few closing comments}

Alternatives to the sequestration process in South Africa should ideally curb the abuse of the sequestration process created by the advantage requirement; provide all debtors with opportunities to pay their creditors in an incentivised manner with the hope of discharge; release certain debtors from their responsibilities earlier; and provide them with a last chance of escaping the sequestration process and avoiding the stigma that accompanies insolvency.

The South African alternatives to sequestration clearly do not provide for a discharge of debts and dismissal (or even avoidance) of insolvency proceedings. Although the Kenyan bankruptcy procedure also excludes certain debtors from the procedure, an important lesson to be learned from the Kenyan insolvency system is that it provides debtors with the option of applying for one of the alternatives to bankruptcy procedures provided by the new Act itself. ${ }^{188} \mathrm{It}$ is submitted that mentioning the alternatives as early as section 14 in the new Act gives the impression that the lawmakers wanted debtors to first be aware of these alternatives before even considering the bankruptcy application in sections 17 and 32 of the new Act, thereby educating debtors about other ways of obtaining a discharge outside of bankruptcy.

Although some of the alternatives, namely the IVA and the expedited procedure, do not provide a discharge on the approval of the proposal, stayed and pending bankruptcies are dismissed. A debtor is therefore able to avoid bankruptcy, its costs and the stigma associated with bankruptcy. While debt review is intended to allow over-indebted debtors to obtain relief from their over-indebtedness while still meeting their financial obligations with the aim of eventually settling their debts, this purpose appears to be

188 The alternatives to bankruptcy are mentioned in $\mathrm{s} 14$ of the new Act before the requirements and procedure for bankruptcy in ss 17, 32 of the new Act. 
defeated if sequestration applications can still be made. It is therefore submitted that the debt review procedure should be amended to permit a debtor to at least be able to avoid sequestration applications during its existence. ${ }^{189}$

The SIO also does not discharge debts during the existence of the order but it suspends all proceedings against the debtor, including bankruptcy proceedings. Its biggest advantage is that it has a determined period of expiration: three years extended to a maximum period of five years. This excuses the debtor from having to pay the instalments for years. To cater for debtors who are unable to make weekly or monthly payments, an arrangement can be made that the instalment be payable every four months. ${ }^{190}$ To reduce the costs of the procedure, the requirement of a supervisor can be dispensed with, and a debtor can still obtain credit of not more than R12 975. Although in Kenya an SIO is essentially effective for the same period as bankruptcy, it is a better alternative than bankruptcy because if successful, debts are paid in full in three years, it avoids bankruptcy and the stigma associated with it, and it may have reduced costs. Be that as it may, the debtor may lose some of his assets if the OR makes an order regarding the disposal of assets. ${ }^{191}$

In South Africa the no asset procedure could be the true alternative to the sequestration procedure. It caters for debtors who have no realisable assets but who have debts between R12 975 and R519 $012 .{ }^{192}$ It suspends all claims against a debtor, including bankruptcy applications. After twelve months from admission, the debtor is discharged from all his debts, including any penalties that may have accrued. The debtor is therefore released from his debts earlier than in bankruptcy, and the debtor avoids bankruptcy completely. In order to advance the re-establishment of a debtor's economic capability, as purposed by the World Bank Report, it is submitted that the South African law makers should consider the alternatives to bankruptcy provisions in the Kenyan Insolvency Act. A debt intervention process should ideally provide a discharge and apply to all debtors (including those with no assets and debts above R50 000) and to all agreements. As the Insolvency Act is the only legislation that provides a

\footnotetext{
189 Section 86(10) of the NCA allows for the termination of debt review should the consumer be in default.

190 See regs 52(2), 71 of the Insolvency Regulations, 2016.

191 Section 327 of the new Act.

192 It would be the legislature's prerogative to determine the amounts that would appear suitable for South African debtors who fall outside the scope of the sequestration process, debt review and administration in terms of the MCA.
} 
process that discharges debts upon rehabilitation, such a debt intervention should ideally be included in the Insolvency Act and preferably before the voluntary surrender and compulsory sequestration processes are explained. That would hopefully make consumers aware of such debt intervention before considering the sequestration process.

\section{Bibliography}

\section{Literature}

Bertelsmann et al Mars

Bertelsman E et al Mars The Law of Insolvency in South Africa $9^{\text {th }}$ ed (Juta Cape Town 2008)

Boezaart Law of Persons

Boezaart T Law of Persons $5^{\text {th }}$ ed (Juta Cape Town 2016)

Boraine, Van Heerden and Roestoff 2012 De Jure

Boraine A, Van Heerden C and Roestoff M "A Comparison between Formal Debt Administration and Debt Review - The Pros and Cons of these Measures and Suggestions for Law Reform (Part 2)" 2012 De Jure 254-271

Coetzee Comparative Reappraisal of Debt Relief Measures

Coetzee H A Comparative Reappraisal of Debt Relief Measures for Natural Person Debtors in South Africa (LLD-dissertation University of Pretoria 2015)

Coetzee 2016 IIR

Coetzee $\mathrm{H}$ "Is the Unequal Treatment of Debtors in natural person Insolvency Law Justifiable? A South African Exposition" 2016 IIR 36-55

Coetzee 2017 THRHR

Coetzee $\mathrm{H}$ "Does the Proposed Pre-liquidation Composition Proffer a Solution to the No Income No Asset (NINA) Debtors' Quandary and, if not, What Would?" 2017 THRHR 18-26

Evans 2002 IIR

Evans RG "The Abuse of the Process of the Court in Friendly Sequestration Proceedings in South Africa" 2002 IIR 13-34

Fletcher Law of Insolvency

Fletcher IF The Law of Insolvency $5^{\text {th }}$ ed (Sweet and Maxwell London 2017) 
Greig 2000 SALJ

Greig MA "Administration Orders as Shark Nets" 2000 SALJ 622-226

Kelly-Louw 2008 SA Merc LJ

Kelly-Louw $M$ "The Prevention and Alleviation of Consumer Overindebtedness" 2008 SA Merc LJ 200-226

Kelly-Louw and Stoop Consumer Credit Regulation

Kelly-Louw M and Stoop PN Consumer Credit Regulation in South Africa (Juta Cape Town 2012)

Mabe 2017 THRHR

Mabe Z "Notice of Intention to Surrender as an Abuse of the Sequestration Process: Nedbank Limited v Malan; In re: Ex Parte Application of Malan [2015] JOL 33458 (GP)" 2017 THRHR 695-703

Mabe and Evans 2014 SA Merc LJ

Mabe $Z$ and Evans RG "Abuse of Sequestration Proceedings in South Africa Revisited" 262014 SA Merc LJ 651-667

Meskin et al Insolvency Law

Meskin PM et al Insolvency Law and its Operation in Winding-up (LexisNexis Butterworths Durban 1990- (June 2015 update))

Nel Analysis of the Legislative Mechanisms

Nel An Analysis of the Legislative Mechanisms Available to Individual Debtors in terms of the South African Law (LLM-dissertation University of South Africa 2006)

Otto National Credit Act Explained

Otto JM The National Credit Act Explained $4^{\text {th }}$ ed (LexisNexis Butterworths Durban 2016)

Paterson Eckard's Principles of Civil Procedure

Paterson TJM Eckard's Principles of Civil Procedure in the Magistrates' Courts $5^{\text {th }}$ ed (Juta Cape Town 2005)

Rochelle 1996 TSAR

Rochelle MR "Lowering the Penalties for Failure: Using the Insolvency Law as a Tool for Spurring Economic Growth: The American Experience, and Possible Uses for South Africa" 1996 TSAR 315-329 
Roestoff Kritiese Evaluasie van Skuldverligtingsmaatreëls

Roestoff M 'n Kritiese Evaluasie van Skuldverligtingsmaatreëls vir Individue in die Suid-Afrikaanse Insolvensiereg (LLD-dissertation University of Pretoria 2002)

Roestoff and Coetzee 2012 SA Merc LJ

Roestoff $\mathrm{M}$ and Coetzee $\mathrm{H}$ "Consumer Debt Relief in South Africa: Lessons from America and England; and Suggestions for the Way Forward" 2012 SA Merc LJ 53-76

Roestoff and Renke 2006 Obiter

Roestoff M and Renke S "Debt Relief for Consumers: The Interaction between Insolvency and Consumer Protection Legislation (Part 2)" 2006 Obiter $98-110$

Scholtz et al Guide to the National Credit Act

Scholtz JW et al Guide to the National Credit Act (LexisNexis Butterworths Durban 2008)

Sharrock, Van der Linde and Smith Hockly's Insolvency Law

Sharrock J, Van der Linde K and Smith A Hockly's Insolvency Law $9^{\text {th }}$ ed (Juta Cape Town 2012)

Smith Law of Insolvency

Smith CH The Law of Insolvency $3^{\text {rd }}$ ed (Butterworths Durban 1988)

Theophilopoulos, Van Heerden and Boraine Fundamental Principles of Civil Procedure

Theophilopolos C, Van Heerden C, and Boraine A Fundamental Principles of Civil Procedure (LexisNexis Butterworths Durban 2015)

Van Heerden and Lötz 2010 THRHR

Van Heerden C and Lötz DJ "Over-indebtedness and Discretion of Court to Refer to Debt Counsellor: Standard Bank of South Africa Ltd v Hales 2009 (3) SA 315 (D)" 2010 THRHR 502-517

Walters 2009 IIR

Walters A "Individual Voluntary Arrangements: A 'Fresh Start' for Salaried Consumer Debtors in England and Wales?" 2009 IIR 5-36 
World Bank Report

World Bank Working Group on the Treatment of the Insolvency of Natural Persons Report on the Treatment of the Insolvency of Natural Persons (World Bank Washington DC 2013)

\section{Case law}

African Bank Ltd v Jacobs 20063 SA 364 (CPD)

African Bank Ltd v Weiner 20054 SA 363 (SCA)

Crafford $v$ Crafford 2014 ZAWCHC 14 (13 February 2014)

Ex parte Arntzen (Nedbank Ltd as Intervening Creditor) 20131 SA 49 (KZP)

Ex parte August 20043 SA 268 (WLD)

Ex parte Erasmus 20151 SA 540 (GP)

Ex parte Ford 20093 SA 376 (WCC)

Ex parte Mark Shmukler-Tshiko and Emma Shmukler-Tshiko 2012 ZAGPJHC 209 (26 October 2012)

Ex parte Snooke 20145 SA 426 (FB)

Ex parte Taljaard 19753 SA 106 (O)

FirstRand Bank v Consumer Guardian 2014 ZAWCHC 27 (4 March 2014)

Fortuin v Various Creditors 20042 SA 570 (CPD)

Investec Bank Ltd v Mutemeri 20101 SA 265 (GSJ)

Kopman v Benjamin 19511 SA 882 (W)

Naidoo v ABSA Bank 20104 SA 597 (SCA)

Nedbank Limited v Malan; In re: Ex parte Application of Malan $2015 \mathrm{JOL}$ 33458 (GP)

Nedbank Limited v Spencer 2015 ZAGPPHC 172 (3 March 2015)

Nedbank Ltd v National Credit Regulator 20113 SA 581 (SCA)

Mahomed v Lockhat Brothers \& Co Ltd 1944 AD 230 
Plumb on Plumbers v Lauderdale 20131 SA 60 (KZD)

Prinsloo v Van Zyl 19671 SA 581

Seyffert v Firstrand Bank Ltd t/a First National Bank 20126 SA 581 (SCA)

Shaban and Co (Pty) Ltd v Plank 19661 SA 59 (OPD)

Standard Bank of SA Ltd v Essop 19974 SA 569 (D)

\section{Legislation}

\section{Australia}

Bankruptcy Act, 1966

Bankruptcy (Estate Charges) Act, 1997

Corporations Act, 2001

Insolvency Law Report Act, 2016

\section{Kenya}

Bankruptcy Act (Cap 53 of the Laws of Kenya)

Children Act (Cap 8 of the Laws of Kenya)

Companies Act (Cap 486 of the Laws of Kenya)

Insolvency Act 18 of 2015

Matrimonial Causes Act (Cap 152 of the Laws of Kenya)

South Africa

Insolvency Act 24 of 1936

Magistrates' Courts Act 32 of 1944

National Credit Act 34 of 2005

National Credit Amendment Act 19 of 2014

\section{United Kingdom}

Bankruptcy (Estate Charges) Act, 1997 
Corporations Act, 2001

Insolvency Act, 1986

\section{Government publications}

\section{Kenya}

Insolvency Regulations, 2016

\section{South Africa}

Circular 6 of 2017 Interpretation of Section 71 of the National Credit Act 34 of 2005

Draft National Credit Amendment Bill, 2018

GN R1411 in GG 19434 of 30 October 1998

National Credit Regulations, 2006

\section{Internet sources}

Money Converter 2018 https://themoneyconverter.com/ZAR/KES.aspx Money Converter Convert South African Rand to Kenyan Shilling (ZAR to KES) (2018) https://themoneyconverter.com/ZAR/KES.aspx accessed 5 June 2018

NCR 2018 http://www.ncr.org.za

National Credit Regulator 2018 Home http://www.ncr.org.za accessed 5 June 2018

NCR 2011 http://www.ncr.org.za/pdfs/Guidelines/2011/Debt_Counselling_Fee_Guidelines.pdf

National Credit Regulator 2011 Debt Counselling Fee Guidelines http://www.ncr.org.za/pdfs/Guidelines/2011/Debt_Counselling_Fee_Guidel ines.pdf accessed 5 June 2018

\section{List of Abbreviations}

IIR International Insolvency Review

ILRA Insolvency Law Report Act, 2016

IVA Individual Voluntary Arrangements

MCA Magistrates' Courts Act 32 of 1944 


$\begin{array}{ll}\text { NCA } & \text { National Credit Act } 34 \text { of } 2005 \\ \text { NCR } & \text { National Credit Regulator } \\ \text { OR } & \text { Official Receiver } \\ \text { SALJ } & \text { South African Law Journal } \\ \text { SA Merc LJ } & \text { South African Mercantile Law Journal } \\ \text { SIO } & \text { Summary Instalment Order } \\ \text { THRHR } & \text { Tydskrif vir Hedendaagse Romeins-Hollandse Reg } \\ \text { TSAR } & \text { Tydskrif vir die Suid-Afrikaanse Reg }\end{array}$

